\title{
Monosodium glutamate (MSG)- obese rats develop glucose intolerance and insulin resistance to peripheral glucose uptake
}

\author{
A.E. Hirata, \\ I.S. Andrade, \\ P. Vaskevicius \\ and M.S. Dolnikoff
}

\author{
Departamento de Fisiologia, Universidade Federal de São Paulo, \\ 04023-900 São Paulo, SP, Brasil
}

\section{Correspondence \\ M.S. Dolnikoff \\ Disciplina de Neurofisiologia e \\ Fisiologia Endócrina \\ Departamento de Fisiologia \\ UNIFESP (EPM) \\ Rua Botucatú, 862, $2^{\circ}$ andar \\ 04023-900 São Paulo, SP \\ Brasil \\ Fax: 55 (011) 570-7675}

Research supported by FAPESP (No. 95/9972-5) and CNPq (No. 520858/94-8).

Received June 5, 1996 Accepted February 20, 1997

\section{Abstract}

Different levels of insulin sensitivity have been described in several animal models of obesity as well as in humans. Monosodium glutamate (MSG)-obese mice were considered not to be insulin resistant from data obtained in oral glucose tolerance tests. To reevaluate insulin resistance by the intravenous glucose tolerance test (IVGTT) and by the clamp technique, newborn male Wistar rats $(\mathrm{N}=20)$ were injected 5 times, every other day, with $4 \mathrm{~g} / \mathrm{kg} \mathrm{MSG}(\mathrm{N}=10)$ or saline (control; $\mathrm{N}=10$ ) during the first 10 days of age. At 3 months, the IVGTT was performed by injecting glucose $(0.75 \mathrm{~g} / \mathrm{kg})$ through the jugular vein into freely moving rats. During euglycemic clamping plasma insulin levels were increased by infusing $3 \mathrm{mU} \cdot \mathrm{kg}^{-1} \cdot \mathrm{min}^{-1}$ of regular insulin until a steady-state plateau was achieved. The basal blood glucose concentration did not differ between the two experimental groups. After the glucose load, increased values of glycemia $(\mathrm{P}<0.001)$ in MSG-obese rats occurred at minute 4 and from minute 16 to minute 32 . These results indicate impaired glucose tolerance. Basal plasma insulin levels were $39.9 \pm 4 \mu \mathrm{U} / \mathrm{ml}$ in control and $66.4 \pm 5.3$ $\mu \mathrm{U} / \mathrm{ml}$ in MSG-obese rats. The mean post-glucose area increase of insulin was 111\% higher in MSG-obese than in control rats. When insulinemia was clamped at 102 or $133 \mu \mathrm{U} / \mathrm{ml}$ in control and MSG rats, respectively, the corresponding glucose infusion rate necessary to maintain euglycemia was $17.3 \pm 0.8 \mathrm{mg} \cdot \mathrm{kg}^{-1} \cdot \mathrm{min}^{-1}$ for control rats while $2.1 \pm 0.3 \mathrm{mg} \cdot \mathrm{kg}^{-1}$. $\mathrm{min}^{-1}$ was sufficient for MSG-obese rats. The 2-h integrated area for total glucose metabolized, in $\mathrm{mg}$. $\mathrm{min}$. $\mathrm{dl}^{-1}$, was $13.7 \pm 2.3$ vs $3.3 \pm 0.5$ for control and MSG rats, respectively. These data demonstrate that MSG-obese rats develop insulin resistance to peripheral glucose uptake.
Key words

- Monosodium glutamate

- Insulin resistance

- Obesity

- Clamp technique 
We have recently shown that plasma insulin (1) and corticosterone levels (2) are increased in monosodium glutamate (MSG)obese rats. Furthermore, it is well known that hyperinsulinemia may induce insulin resistance in experimental models of obesity (3). However, from previous data obtained in oral glucose tolerance tests, MSG-obese mice have been considered not to be resistant to insulin (4). Recently, glucose transporters (GLUT4) have been shown to be decreased in insulin-sensitive tissues of MSG-obese mice (5).

The aim of the present study was to reevaluate insulin resistance in MSG-obese rats using the intravenous glucose tolerance test (IVGTT) and the euglycemic hyperinsulinemic clamp technique.

Newborn male Wistar rats were injected with monosodium glutamate (MSG-obese rats) or saline (control rats), as previously described (2). At the age of 90 days, freely moving rats ( 6 rats per group) were deprived of food for $6 \mathrm{~h}$ and then submitted to IVGTT. One day before the test, the animals were anesthetized with pentobarbital $(50 \mathrm{mg} / \mathrm{kg}$ body weight) and indwelling catheters were inserted into the right jugular vein for glu-

Figure 1 - Time course of blood glucose (A) and insulin concentrations (B) before and after 0.75 $\mathrm{g} / \mathrm{kg}$ glucose infusion in MSGobese rats. Data are reported as means \pm SEM for 6 rats in each group. ${ }^{*} \mathrm{P}<0.001$ compared to saline control (one-way analysis of variance (ANOVA) followed by the Mann-Whitney U-test). cose infusion and into the right femoral artery for blood sampling. Glucose $(0.75 \mathrm{~g} / \mathrm{kg}$ body weight) was quickly injected and blood samples for insulin and glucose evaluations were drawn 4, 8, 12, 16, 20, 24, 28 and 32 min after injection. For euglycemic hyperinsulinemic clamp (8 rats per group) a prime continuous $\left(3.0 \mathrm{mU} \cdot \mathrm{kg}^{-1} \cdot \mathrm{min}^{-1}\right)$ infusion of regular insulin (Neosulin, Biobrás, Montes Claros, MG, Brazil) was administered from time 0 to raise plasma insulin and to maintain it at a steady-state plateau (90-120 min). Glucose infusion (10\% D-glucose) was started 5 min after the beginning of the experiment and was corrected, when necessary, to maintain euglycemia at about $100 \mathrm{mg} / \mathrm{dl}$ (6). Plasma glucose was measured with a glucometer 4 (Ames, Elkhart, IN) and plasma insulin by radioimmunoassay (7). Results are reported as mean \pm SEM and statistical comparisons were performed using ANOVA followed by the Mann-Whitney U-test.

Figure 1A shows the results of the IVGTT. Basal blood glucose levels were similar in MSG-obese and control rats. After glucose load, glucose concentration at minute 4 reached significantly higher values in MSGobese than in control rats. From minute 16 up to minute 32, MSG rats showed a significantly $(\mathrm{P}<0.001)$ increased glycemia when compared to control rats. The area under the curve of blood glucose concentration $(\Delta \mathrm{G})$ was higher $(\mathrm{P}<0.001)$ in MSG-obese $(192.7$ $\left.\pm 14.4 \mathrm{mg} \cdot \mathrm{min} \cdot \mathrm{dl}^{-1}\right)$ than in control rats $\left(139.1 \pm 9.2 \mathrm{mg} \cdot \mathrm{min} \cdot \mathrm{dl}^{-1}\right)$. The glucose disappearance rate, when calculated as the $\mathrm{K}$ index, was also significantly lower $(\mathrm{P}<0.001)$ in MSG-obese $(4.24 \pm 0.3)$ than in control $(6.25 \pm 0.3)$ rats. These results are opposite of those obtained in MSG-treated mice (4) or rats (8).

As shown in Figure 1B, plasma insulin levels were significantly higher in MSGobese $(66.4 \pm 5.3 \mu \mathrm{U} / \mathrm{ml})$ than in control rats $(39.9 \pm 4.0 \mu \mathrm{U} / \mathrm{ml})$. Hyperinsulinemia has already been demonstrated in rats (1), mice (4) and golden hamsters (9) neonatally treated 
with monosodium glutamate.

After the glucose load, plasma insulin concentration reached the highest values in MSG-obese rats. In fact, the mean postglucose area increase of insulin $(\Delta \mathrm{I})$ was $121.7 \pm 11.6 \mu \mathrm{U} . \min . \mathrm{ml}^{-1}$ in MSG-obese and $57.77 \pm 7.6 \mu \mathrm{U} . \mathrm{min} . \mathrm{ml}^{-1}$ in control rats $(\mathrm{P}<0.001)$. The insulinogenic index $(\Delta \mathrm{I} / \Delta \mathrm{G})$ was also increased $(600 \pm 26 \mu \mathrm{U} / \mathrm{mg}$ for MSG vs $400 \pm 18 \mu \mathrm{U} / \mathrm{mg}$ for control rats). Despite the fact that obese MSG-treated mice cleared an intravenous glucose load more rapidly than the control animals (4), our data indicate significantly higher blood glucose and plasma insulin levels in response to an IVGTT challenge in MSG-obese than in control rats. This fact suggests that MSG-obese rats develop glucose intolerance and/or an insulin-resistant state.

There is evidence that hyperinsulinemia could play an important role in the development of hypersensitivity to insulin and obesity.

We have previously shown in adipocytes pre-incubated for $2 \mathrm{~h}$ that both the basal glucose uptake rate and the maximal response to insulin are significantly higher in cells from MSG-obese rats compared to control cells (1). However, it is true that longterm hyperinsulinemia induces a state of resistance to insulin $(10,11)$. To test this possibility, clamp studies were performed in another group of animals. In these experiments plasma insulin concentration was raised acutely and maintained at approximately $101.8 \pm 7.8 \mu \mathrm{U} / \mathrm{ml}$ (control rats) or $133.1 \pm 8.0 \mu \mathrm{U} / \mathrm{ml}$ (MSG-obese rats) by a prime continuous infusion of insulin. During the equilibration period (reached after 90$120 \mathrm{~min}$ ) basal glucose concentration was similar for both experimental groups (100.7 $\pm 3.2 \mathrm{mg} / \mathrm{dl}$ in control and $100.1 \pm 2.2 \mathrm{mg} / \mathrm{dl}$ in MSG-obese rats; Figure 2A,B). Coefficients of variation of blood glucose and plasma insulin levels during the euglycemic hyperinsulinemic clamp were 3 and 10\%, respectively. Figure 2 shows that the glucose
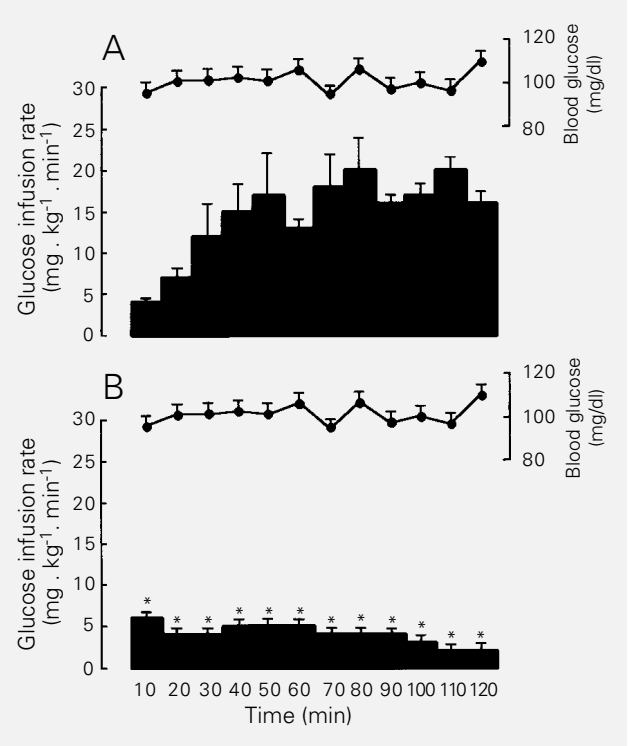

infusion rate necessary to maintain euglycemia was $17.3 \pm 0.8 \mathrm{mg} \cdot \mathrm{kg}^{-1} \cdot \mathrm{min}^{-1}$ for control rats (Figure 2A) while a rate of $2.1 \pm$ $0.3 \mathrm{mg} \cdot \mathrm{kg}^{-1} \cdot \mathrm{min}^{-1}$ was sufficient for MSGobese rats (Figure 2B). The 2-h integrated area for total glucose metabolism was $13.7 \pm$ $2.3 \mathrm{mg} \cdot \mathrm{min} . \mathrm{dl}^{-1}$ in control and $3.3 \pm 0.5$ $\mathrm{mg} \cdot \mathrm{min} . \mathrm{dl}^{-1}$ in MSG rats, i.e., despite the high value of insulinemia, glucose uptake was 4 times lower in MSG-obese animals than in the control group.

In the clamp studies the blood glucose concentration was held constant at basal levels by a variable glucose infusion using the negative feedback principle (6). Under these steady-state conditions of euglycemia, the glucose infusion rate equals glucose uptake in all body tissues and is therefore a measure of tissue sensitivity to exogenous insulin. In MSG-obese rats the 8.2 times lower glucose infusion rate (Figure 2B) suggested a reduced ability of insulin to stimulate glucose utilization resulting in insulin resistance, as now proposed for the first time. In fact, several situations of insulin resistance in man, as well as in animal models, show some degree of hypercorticism $(12,13)$. Since MSG-obese rats have high plasma levels of corticosterone (2) it is possible that this hor-
Figure 2 - Blood glucose concentration and glucose infusion rates during the insulin clamp studies performed in control (A) and MSG-obese (B) rats. Data are reported as means \pm SEM for 8 rats in each group. ${ }^{*} \mathrm{P}<0.001$ compared to saline control (one-way analysis of variance (ANOVA) followed by the Mann-Whitney U-test). 
mone plays an important role in this metabolic alteration (14). Further investigations are currently underway to clarify if a decreased GLUT4 content is present in skeletal muscle of MSG-obese rats like in other experimental obesity models $(5,15)$.

\section{Acknowledgments}

We are grateful to Dr. O. Kohlmann Jr. for the facilities provided during the execution of this study, and especially to Milton Ginoza for excellent technical assistance.

\section{References}

1. Marmo MR, Dolnikoff MS, Kettelhut IC, Matsuchita DM, Hell NS \& Lima FB (1994). Neonatal monosodium glutamate treatment increases epididymal adipose tissue sensitivity to insulin in three-month old rats. Brazilian Journal of Medical and Biological Research, 27: 1249-1253.

2. Dolnikoff MS, Kater CE, Egami M, Andrade IS \& Marmo MR (1988). Neonatal treatment with monosodium glutamate increases plasma corticosterone in the rat. Neuroendocrinology, 48: 645-649.

3. Le Marchand $Y$, Freychet $P$ \& Jeanrenaud B (1978). Longitudinal study on the establishment of insulin resistance in hypothalamic obese mice. Endocrinology, 102: 7485.

4. Cameron DP, Cutbush L \& Opat F (1978). Effects of monosodium glutamate-induced obesity in mice on carbohydrate metabolism in insulin secretion. Clinical and Experimental Pharmacology and Physiology, 5: 41-51.

5. Machado UF, Shimizu Y \& Saito M (1993). Decreased glucose transporter (GLUT 4) content in insulin-sensitive tissues of obese aurothioglucose and monosodium glutamate-treated mice. Hormone and Metabolic Research, 25: 462-465.
6. De Fronzo R, Tobin JD \& Andres R (1979) Glucose clamp technique: a method for quantifying insulin secretion and resistance. American Journal of Physiology, 237: E214-E223.

7. Morgan CR \& Lazarow A (1963). Immunoassay of insulin: two antibody system. Plasma insulin levels of normal, subdiabetic and diabetic rats. Diabetes, 12: 115 126.

8. Lengvári I (1977). Effect of perinatal monosodium glutamate treatment on endocrine functions of rats in maturity. Acta Biologica Academiae Scientiarum Hungaricae, 28: 133-141.

9. Sartin JL, Lamperti AA \& Kemppainen RJ (1985). Alterations in insulin and glucagon secretion by monosodium glutamate lesions of the hypothalamic arcuate nucleus. Endocrine Research, 11: 145-155.

10. Wardazala LJ, Hirschman M, Pofcher E, Horton ED, Mead PM, Cushman SM \& Horton ES (1985). Regulation of glucose utilization in adipose cells and muscle after long-term experimental hyperinsulinemia in rats. Journal of Clinical Investigation, 76: 460-469.
11. Matsuo T \& Shino S (1972). Induction of diabetic alterations by goldthioglucose obesity in KK, ICR and C57BL mice. Diabetologia, 8: 391-397.

12. Nosadini R, Del Porto S \& Tiengo A (1983). Insulin resistance in Cushing's syndrome. Journal of Clinical Endocrinology and Metabolism, 57: 529-536.

13. Guillaume-Gentil $C$, Rohner-Jeanrenaud F, Bestetti GE, Abramo F, Rossi GL \& Jeanrenaud $B$ (1990). Abnormal regulation of the hypothalamo-pituitary-adrenal axis in the genetically obese fa/fa rat. Endocrinology, 126: 1873-1879.

14. Guillaume-Gentil C, AssimacopoulosJeannet F \& Jeanrenaud B (1993). Involvement of non-esterified fatty acid oxidation in glucocorticoid-induced peripheral insulin resistance in vivo in rats. Diabetologia, 36: 899-906.

15. Handberg A, Kayser L, Hoyer PE, Voldstedlund M, Hansen HP \& Vinten J (1993). Metformin ameliorates diabetes but does not normalize the decreased GLUT4 content in skeletal muscle of obese (fa/fa) Zucker rats. Diabetologia, 36: 481-486. 